\title{
SREDNJOVJEKOVNA ARHEOLOŠKA NALAZIŠTA U PODGORJU
}

Radomir Jurić

Brne Krnarutića 7/3

HR 23000 Zadar

rjuric@unizd.hr

Iva Škoro

Vukovarska 95

HR 51265 Dramalj

iva.skoro13@gmail.com
UDK: 902/904(497.5 Podgorje)

Pregledni članak

Ur.: 2017-03-12

Na prostoru od Senja do Maslenice evidentirano je više srednjovjekovnih nalazišta. To su utvrde, sakralni objekti i groblja od 5. do 16. stoljeća. Obradit će se arheološki lokaliteti i pripadajući nalazi s područja Senja, Sv. Jurja, Starigrada Senjskog, Stinice, Prizne, Jablanca, Karlobaga, Starigrada Paklenice i Rovanjske, koji pripadaju ranom kršćanstvu i hrvatskom srednjovjekovlju. Prinos se temelji na rezultatima prethodnih arheoloških istraživanja i rekognosciranja koja su već poznata te vlastitih istraživanja.

Ključne riječi: Podgorje, Senj, rano kršćanstvo, srednji vijek, utvrde, crkve, samostani

Anonim iz Ravene, pisac djela Kozmografija, s kraja 6. i početka 7. stoljeća, navodi civitates raspoređene uz obalu velebitskog Podgorja od jugoistoka prema sjeveru. Ravenatu su na tom području poznati Argerunto, koji se smješta na širi starigradski prostor, zatim Bigi na prostoru Karlobaga, Ospela na prostoru Stinice, Puplisca na prostoru Sv. Jurja te Senia. ${ }^{1}$ Ravenjanin jedini spominje pojam Tarsatičke Liburnije koja obuhvaća sjeverozapadni dio izvorne provincije Dalmacije, zatim cijeli liburnski zaljev koji uključuje Velebitski kanal s Novigradskim i Karinskim morem te dio obale današnje sjeverne Dalmacije s

${ }^{1}$ Ž. TOMIČIĆ, 1990, 140-141; S. ČAČE, 1995, 80. 
Ninom. ${ }^{2}$ Zanimljivo je podudaranje naselja u Ravenatovoj Tarsatičkoj Liburniji s Plinijevim popisom u kojem su navedena oppida od provincijske granice na Raši do Nina. ${ }^{3}$ Cilj ovog članka je napraviti kratku topografiju poznatih srednjovjekovnih lokaliteta na prostoru od Senja do Rovanjske, uključujući okolno područje grada Senja koje možda ne spada u prostor velebitskog Podgorja, no smatram nužnim navesti neke lokalitete s područja grada Senja zbog povijesne povezanosti s Podgorjem te ulogom samog grada Senja u srednjem vijeku.

Započet ćemo s utvrdama na navedenom području, zatim ćemo izdvojiti nekoliko sakralnih objekata i nekoliko ranokršćanskih i srednjovjekovnih arheoloških nalaza. Utvrde i sakralne objekte kratko prikazujemo od sjevera prema jugu.

\section{UTVRDE}

\section{Starigrad Senjski}

Iznad mjesta Starigrad Senjski, između dvije uvale, uzdiže se gradina Golubić-grad s koje potječu brojni arheološki nalazi. Prema predaji, na tom brijegu je u 11. stoljeću izgrađeno srednjovjekovno naselje koje prethodi današnjem Starigradu Senjskom. ${ }^{4}$ U ranom srednjem vijeku Starigrad je dio senjskog kotara, a od 1271. u posjedu krčko-senjskih knezova Frankopana. $\mathrm{Na}$ vrhu brijega nalazi se moguće srednjovjekovno utvrđenje i stariji bizantski ili gotski kastrum. Od 1469. godine utvrda je u sastavu senjske primorske kapetanije. Početkom 16. st. zbog turske opasnosti, starosjedioci su se iselili u sigurnije krajeve. ${ }^{5}$ Do početka 16 . stoljeća, na području Starigrada, nalazila se jedna manja organizirana "vlaška zajednica" nepoznata imena, a krajem 16. stoljeća ona se posve asimilirala s većinskim hrvatskim stanovništvom. ${ }^{6} \mathrm{Na}$ jugoistočnoj padini Golubića nalaze se ruševine romaničke crkve posvećene sv. Jeleni. ${ }^{7}$ Na padinama gradine ima površinskih nalaza, vjerojatno se radi o prapovijesnoj, rimskoj i srednjovjekovnoj keramici koja se često nalazi na starim naseljima. ${ }^{8}$

\footnotetext{
${ }^{2}$ S. ČAČE, 1995, 79.

${ }^{3}$ S. ČAČE, 1995, 79-80.

${ }^{4}$ A. GLAVIČIĆ, 2003, 35.

${ }^{5}$ A. GLAVIČIĆ, 1966, 395.

${ }^{6}$ S. PAVIČIĆ, 1966, 332-333; A. GLAVIČIĆ, 2003, 35.

${ }^{7}$ S. PAVIČIIĆ, 1966, 323; A. GLAVIČIĆ, 1966, 395.

${ }^{8}$ A. GLAVIČIĆ, 1966, 395.
} 


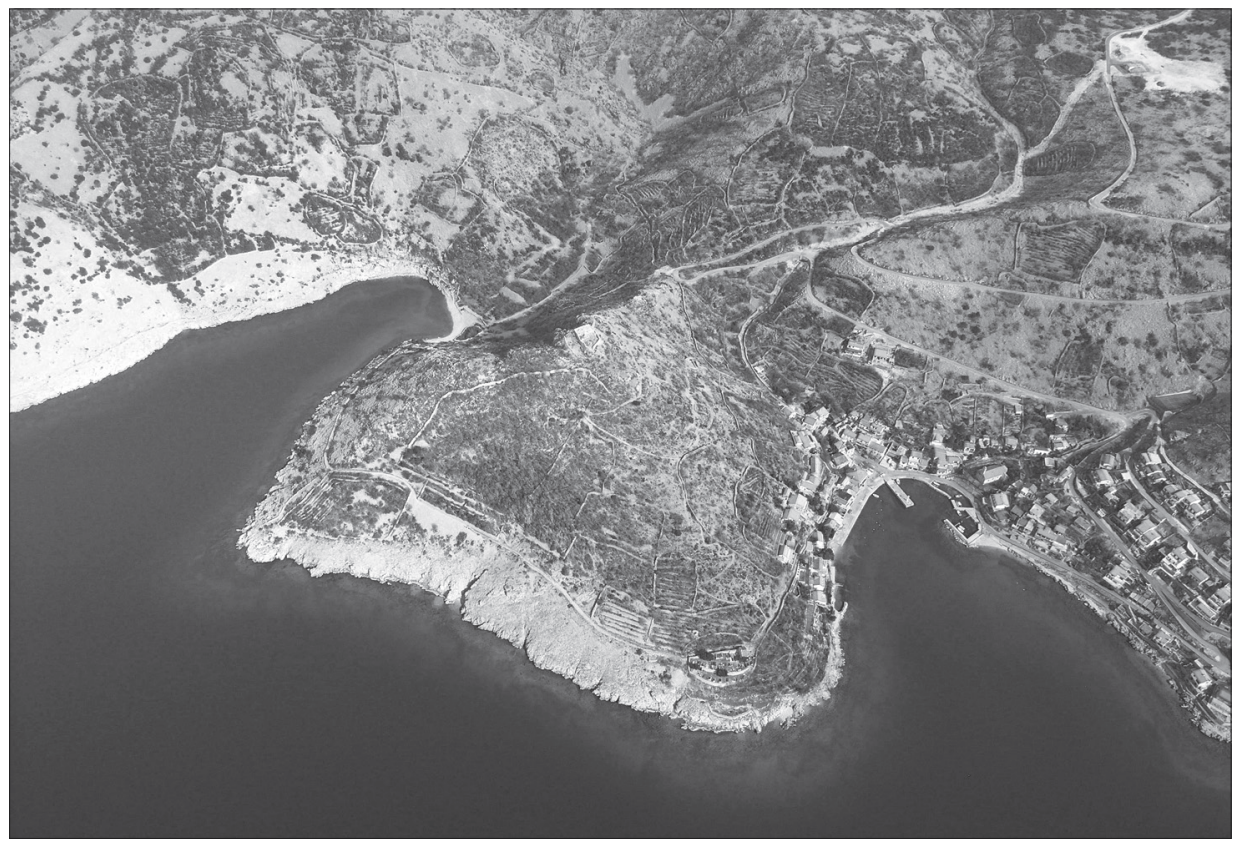

Sl. 1. Gradina Golubić iznad Starigrada Senjskog, foto: Vedrana Glavaš

\section{Stinica}

Prema jugu nalazi se naselje Stinica, odnosno srednjovjekovna Murula. Šetajući se po malom izbočenom poluotoku Punti mogu se vidjeti brojni zidovi i podzidi te puno površinske keramike. Pretpostavlja se kako se radi o ostatcima manjeg utvrđenog trgovačkog naselja, a mjesto se u starohrvatskim ispravama spominje kao castrum. ${ }^{9}$ Murula je od 8 . stoljeća bila vjersko i upravno središte jablanačkog kraja, pa je prema tome morala imati crkvene građevine koje su vjerojatno propale pod zubom vremena. No, nešto se očuvalo u toponimiji. Biškupica je stari naziv za morsku dragu između Stinice i Jablanca. Sam naziv nam govori kako se tu mogao nalaziti neki sakralni objekt rapskog biskupa. ${ }^{10}$ Nakon 1102. godine Stinica se napušta, moguće kako je stradala u ratovima hrvatsko-ugarskog vladara s Rabljanima ili Venecijom. U to vrijeme počinje jačati obližnje mjesto Albanić, današnji Jablanac. ${ }^{11}$

${ }^{9}$ A. GLAVIČIĆ, 2003, 35.

${ }^{10}$ A. GLAVIČIĆ, 2003, 36; Treba istaknuti kako su ovi krajevi do kraja 1154. godine bili pod jurisdikcijom rapskog biskupa, a nakon 1154., Senj postaje biskupija.

${ }^{11}$ A. GLAVIČIĆ, 2003, 35. 


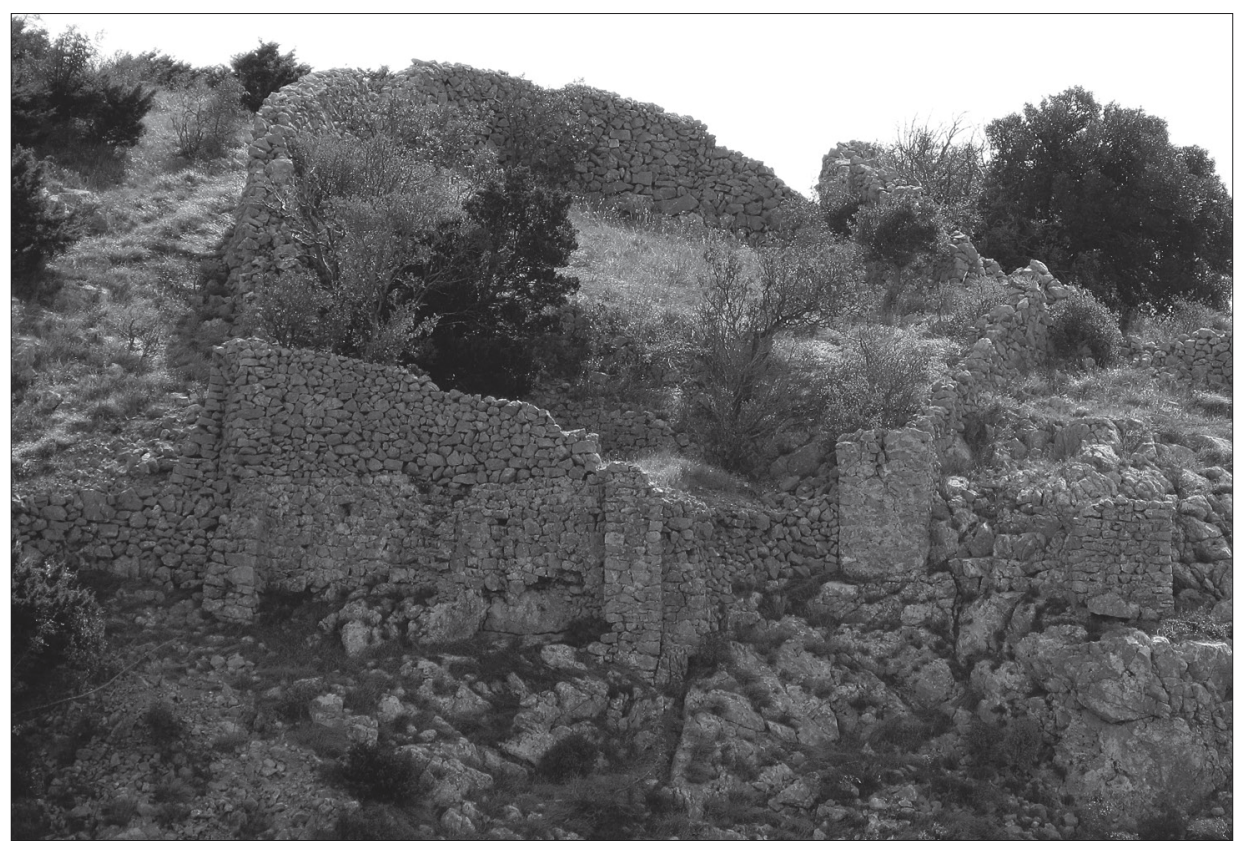

S1. 2. Sačuvani objekt s kontraforima na Gradini u Donjoj Prizni, foto: Iva Škoro

\section{Gradina u Donjoj Prizni}

Bizantski kastrum nalazio se i na stjenovitom poluotoku u Donjoj Prizni. Iznad mjesta uzdiže se Gradina ${ }^{12}$, koja od davnina štiti uvalu od juga. Poluotok se od svoje najviše topografske točke postupno spušta i proširuje prema moru u obliku terasa na kojima se vide ostatci brojnih zidova, podzidova i pravokutnih objekata. ${ }^{13} \mathrm{Na}$ zapadnoj strani iz krševitog terena uzdižu se dijelovi jednog dobro sačuvanog objekta ojačanog kontraforima. Zidine prate konfiguraciju terena, a kastrum završava izbočenim bedemom na najvišoj koti na istočnoj strani. Unutar kastruma prikupljeno je dosta keramike, među kojom se ističu ulomci tipični za bizantsku keramiku, kao i masive ručke većih posuda. ${ }^{14} \mathrm{Uz}$ južnu stranu bedema nalazi se manja zidana cisterna za vodu, kakva se inače susreće na nizu primjera

${ }^{12}$ A. GLAVIČIĆ, 1966, 398; Glavičić je obišao ovaj lokalitet te zaključio kako se tu nalazilo prapovijesno i rimsko naselje u suhozidu koje je u srednjem vijeku zamijenjeno zidanim kućama. Ostaci koje se i danas vide pripadali su nekom naselju nepoznatog imena koje je nastalo u ranom srednjem vijeku, njegova je prošlost nepoznata čak i pučkoj predaji.

${ }^{13}$ A. GLAVIČIĆ, 1966, 398; 1967/1968, 292.

14 Ž. TOMIČIĆ, 1990, 143. 


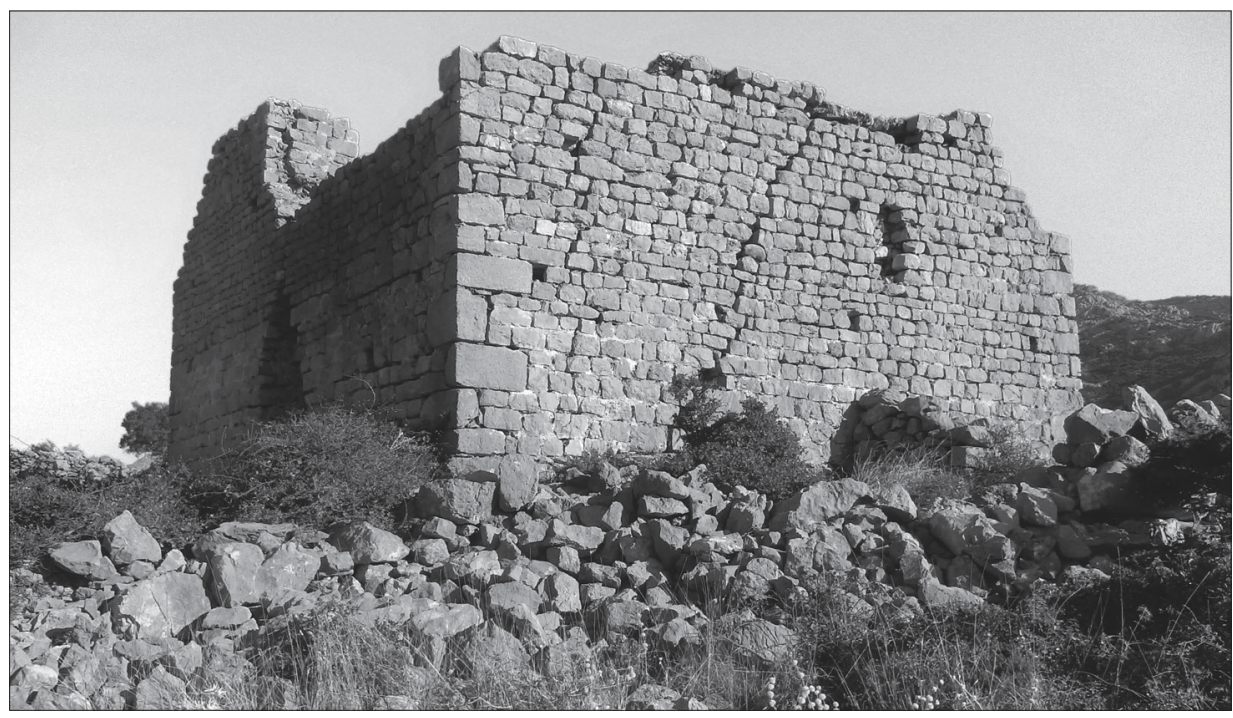

S1. 3. Utvrda na Drvišici, foto: Iva Škoro

ranog bizantskog vojnog graditeljstva duž Jadrana. ${ }^{15}$ Kastrum se dobro vidi s morske strane prigodom plovidbe Velebitskim kanalom kao i sa sjeverne obale otoka Paga, gdje se javlja još jedan ranobizantski kastrum u uvali Sutojašnica. ${ }^{16}$ Ovaj kastrum nalazi se na najužem dijelu Podgorskog kanala te je zajedno sa suprotnim na otoku Pagu, osiguravao kontrolu plovnog puta u ovom dijelu Tarsatičke Liburnije. ${ }^{17}$

\section{Karlobag-Drvišica}

Iznad Karlobaga nalazi se gradina Drvišica koja sadrži ostatke iz prapovijesnog, antičkog i srednjovjekovnog perioda. Na vrhu gradine, na umjetno stvorenom platou, nalazi se zidana kula, veličine je 7 x 7 metara, a visoka 6 metara te se u sklopu utvrde nalazi i bunar. Tradicija navodi kako se radi o turskoj kuli - tzv. džamiji. To ime nije opravdano jer Karlobag nikada nije bio pod Turcima. ${ }^{18}$ Malo toga možemo sa sigurnošću reći o kuli na Drvišici jer još nisu provedena arheološka istraživanja koja bi trebala utvrditi dataciju

${ }^{15}$ Ž. TOMIČIĆ, 1990, 143.

16 Ž. TOMIČIĆ, 1990, 143.

${ }^{17}$ Ž. TOMIČIĆ, 1990, 144.

${ }^{18}$ A. GLAVIČIĆ, 1996, 55-56. 
kule u srednji vijek, ili možda kasnu antiku. Treba spomenuti i Forticu u gradu Karlobagu, koju kao svoje utvrđenje podižu knezovi Kurjakovići u 14. stoljeću. ${ }^{19}$ Utvrda je nadgledala plovidbu između obale i otoka Paga te branila grad.

\section{Kastrum Sveta Trojica}

Položaj Sveta Trojica nalazi se sjeverozapadno od Starigrada Paklenice, kod mjesta Tribanj Šibuljina. Gotovo odmah iznad Jadranske magistrale nalaze se ostatci kasnoantičkog bizantskog kastruma iz 6. stoljeća. ${ }^{20}$ Veoma je dobro očuvan sjeverni dio bedema kastruma koji se može pratiti u dužini od 120 metara. Na njega su prislonjene kule četvrtastog oblika. Unutar bedema koji je sigurno štitio naselje sve do obale na južnoj strani, prepoznaju se tlorisi nastambi koje prekrivaju terasasti plato. Ovo je jedna od najvećih poznatih utvrda iz 6 . stoljeća na našoj obali. ${ }^{21}$ Unutar bedema i kula primjećuju se ostatci kasnoantičke arhitekture, a središnji dio je uništen u novije vrijeme. U sredini utvrđenja nalazi se crkva sv. Trojice, a pojedini njezini ostatci upućuju na veću starost, vjerojatno u 6. stoljeće, znači na istodobnost crkve i primarnog egzistiranja utvrde. Iseljenjem starosjedilaca u vrijeme turske opasnosti crkva je propala. ${ }^{22}$ Pretpostavlja se kako se Ravenatov Argerunto nalazio na položaju Sv. Trojice.

S položaja Sv. Trojice može se vizualno komunicirati s utvrdom na položaju Gradina iznad Modriča i osobito s onom na Rtu Ljubljana iznad Ljubačkog zaljeva između otoka Paga i prostora Ravnih kotara. Ova utvrda je vjerojatno služila kao refugij. ${ }^{23}$

\section{Utvrde Paklarić-grad i Večka Kula}

Nad kanjonom Velike Paklenice, kroz koji je prolazila jedna od glavnih komunikacija zadarskog zaleđa s Likom, nalaze se djelomice istraženi ostatci obrambenog sustava iz kasnog srednjeg vijeka. ${ }^{24}$ Naime, na mjestu prapovijesne željeznodobne gradine, $\mathrm{tj}$. na istočnom dijelu platoa izgrađen je obrambeni zid s kulom, dok se ostatci veće kule trapezoidnog oblika nalaze na zapadnom, strmom rubu platoa.

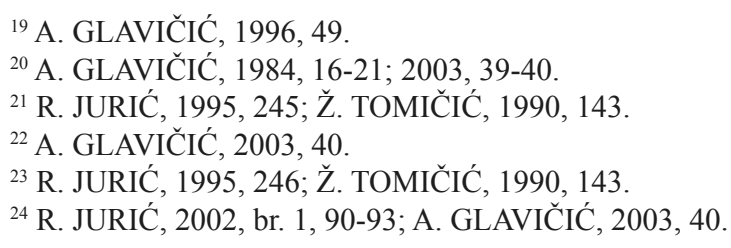




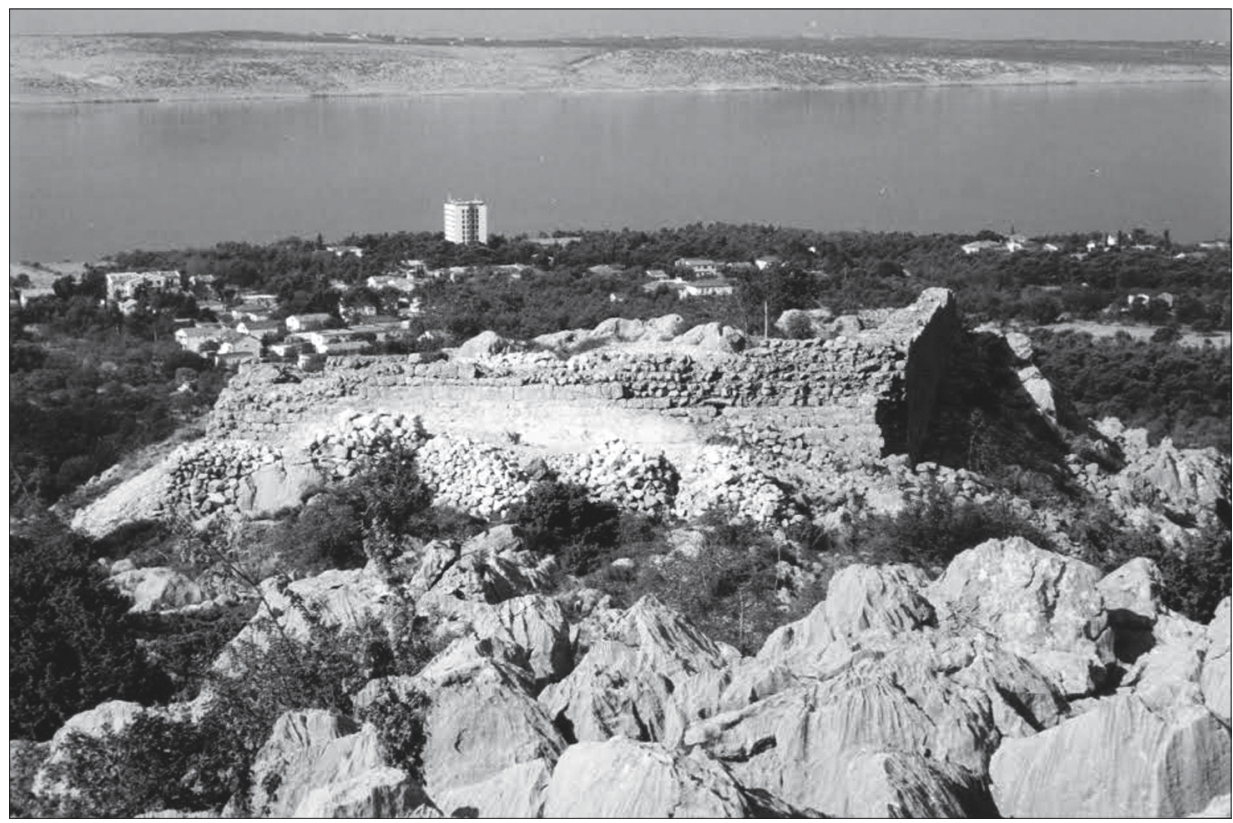

S1. 4. Utvrda Paklarić iznad Starigrad Paklenice, foto: Franjo Nedved

Na položaju Kulina, tik uz more i u moru, na rtu (nasuprot Vinjerca), odnosno između Starigrada i Selina nalazi se Večka kula, danas poprilično dobro sačuvana. Vjerojatno je iz konca 15. i početka 16. stoljeća i pripada nizu mletačkih utvrda koje su podignute radi pregleda plovidbe i obrane od Turaka. Valjkasta kula je na kopnu, dok je njezin četvrtasti dio koji se nalazi s južne strane, većim dijelom u moru.

\section{Utvrda nad Modričem}

U blizini Rovanjske nad uvalom Modrič, neposredno iznad Jadranske magistrale, na položaju Gradina, nalazi se utvrda relativno pravokutnog tlocrta s izbočenim četvrtastim kulama, koja dobro nadzire Ljubački zaljev. Tehnika gradnje bedema, tlorisna osnova utvrđenja te njezina orijentiranost moru govori nam kako se radi o vojnom graditeljstvu nastalom tijekom kasne antike. Riječ je o utvrđenju koje ima izuzetno značajnu ulogu. Svojim položajem ono otežava kopneni pristup Starigradu Paklenici. ${ }^{25}$ Moguće je kako je ova utvrda imala i funkciju refugija u

${ }^{25}$ Ž. TOMIČIĆ, 1990, 142; R. JURIĆ, 1995, 245. 
tom dijelu velebitskoga Podgorja. Još jedna takva utvrda možda se nalazila i na položaju Dračevac kod Rovanjske, odnosno Jasenica. Arheološka istraživanja bi mogla odbaciti ili potvrditi ovakvu pretpostavku. Međutim, na tom dominantnom položaju danas strše ostatci srednjovjekovne utvrde.

Utvrda nad Modričem, zajedno s utvrdom u Donjoj Prizni, utvrdom Sv. Trojica i još nizom drugih lokaliteta pripisuje se rekonkvisti bizantskog cara Justinijana I., odnosno razdoblju gotsko-bizantskog ratovanja duž istočnojadranskog priobalja, kada je izgrađeno više takvih utvrda, koje su osiguravale plovni put štiteći ujedno i obalno stanovništvo. Sigurno je i kako su ove utvrde štitile pristup prema gorskim prijevojima Velebita. ${ }^{26}$

\section{SAKRALNI OBJEKTI}

\section{Pavlinski samostan i crkva sv. Jelene kod Senja}

U Vlaškoj dragi, oko $4 \mathrm{~km}$ zapadno od Senja, nalaze se ruševine na samoj morskoj obali. Radi se o ostatcima glagoljaškog pavlinskog samostana i crkve sv. Jelene, koju je 1390. godine osnovao Radovan, kanonik i arhiđakon senjske biskupije. Glavičić piše kako se u crkvi vide sačuvani gotički ostatci svodova i zidova sa neznatnim ostatcima fresaka. ${ }^{27}$ Bez obzira što freske nisu sačuvane ili još neke nisu utvrđene, one svjedoče kako su senjske i podgorske srednjovjekovne crkve bile oslikane kao što je to bilo uobičajeno u crkvama u Istri i na otocima Hrvatskog primorja. Pretpostavlja se kako su se u crkvi i oko nje pokapali redovnici samostana i stanovnici okolnih zaselaka. Ako je pokapanja bilo, ono je vjerojatno prestalo ukinućem pavlina 1785. godine..$^{28}$

\section{Crkva sv. Marije u Senju}

Prostor na kojem se nalazi katedrala sv. Marije predodređen je za izgradnju sakralnih građevina, prvo poganskih, zatim kršćanskih. ${ }^{29}$ Zahvaljujući istraživanjima Ranka Starca znamo kako se na tom prostoru nalazio starokršćanski kompleks. ${ }^{30}$ Prije početka 12 . stoljeća morala je postojati neka manja predromanička crkva, jer se u 12. stoljeću gradi jednobrodna romanička

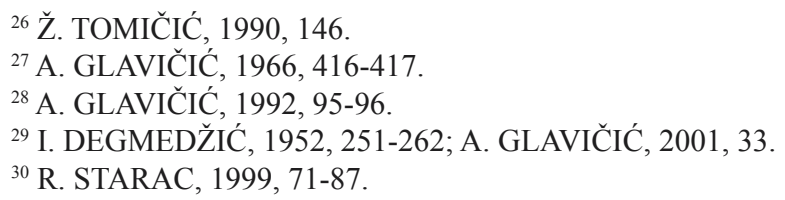


bazilika s četvrtastom apsidom. Početkom 18. stoljeća crkva je adaptirana u trobrodnu te dobiva svoj današnji izgled. ${ }^{31}$ Čitav prostor oko katedrale od kasne antike, kroz rani i kasni srednji vijek sve do 18. stoljeća bio je korišten kao gradsko groblje o čemu svjedoči sam toponim trga Cimiter, gdje su pokapani mnogi Senjani tokom srednjeg vijeka. Grobovi su koncentrirani s južne strane katedrale i ograđeni zidom koji se očuvao do danas. ${ }^{32}$

Osim istraživanja Ivice Degmedžića, Ante Glavičića i Ranka Starca, svakako treba spomenuti i radove Melite Viličić, koja nam je ponudila tlocrte i rekonstrukcije katedrale. ${ }^{33}$

\section{Crkva sv. Jurja (senjski i svetojurski)}

Pri obnovi tvrđave Nehaj 1964. godine, u južnom dijelu prizemlja otkriveni su ostatci male romaničke jednobrodne crkve s polukružnom apsidom i ostatcima oltara. Unutar crkve naišlo se i na ostatke grobova. Smatra se kako se radi o crkvi sv. Jurja, najstarijoj do danas otkrivenoj senjskoj crkvi. ${ }^{34}$ Crkva sv. Jurja spominje se 1184. godine u darovnici kralja Bele III. iz koje doznajemo kako su templari dobili ovu crkvu s njezinim posjedima, što znači da je crkva morala biti starija od te godine. U posjedu templara bila je do 1269 . godine, a nakon njihova odlaska iz Senja crkvu nasljeđuju benediktinci sve do turskih provala. Po odluci kapetana Ivana Lenkovića, crkva je razgrađena oko 1550. godine. ${ }^{35} \mathrm{Iz}$ darovnice saznajemo kako se crkva nalazila izvan grada, neki autori je ubiciraju u Abatovo na Trbušnjaku, dok drugi, poput Ante Glavičića, smatraju kako je crkva sv. Jurja upravo ova otkrivena u temeljima tvrđave Nehaj. ${ }^{36}$ Drugi smatraju kako crkva sv. Jurja i benediktinski samostan uopće nisu bili u Senju već u Svetom Jurju. No, bez obzira na pretpostavke i nerazriješeno pitanje lokacije samostana i crkve sv. Jurja senjskog te samostana sv. Jurja Lisačkog, odnosno svetojurskog, dvije crkve su sigurno postojale, i to

${ }^{31}$ A. GLAVIČIĆ, 1966, 411-412; 2001, 38; 2003, 26;

${ }^{32}$ A. GLAVIČIĆ, 1966, 411-412; 2003, 26.

${ }^{33}$ M. VILIČIĆ, 1968, 57.

${ }^{34}$ A. GLAVIČIĆ, 1965, 320; 2003, 27.

${ }^{35}$ A. GLAVIČIĆ, 1965, 321; 2003, 27.

${ }^{36}$ A. GLAVIČIĆ, 1999, 97; 2003, 28; U srednjem vijeku brdo iznad grada Senja, od Arta do Abatova, zvalo se Brdo svetog Jurja. Mjesto na vrhu brda Nehaj prema ranijim vjerovanjima imalo je neko pogansko značenje. Tu se nalazila predrimska i rimska nekropola, a moguće i starohrvatsko svetište Svatovida, odnosno Peruna. Sve ovo nam potvrđuje kako je crkva sv. Jurja podignuta na brdu iznad grada nastavlja neku raniju pogansku tradiciju. Inače crkve posvećene svetcima ratnicima podižu se na uzvisinama. 
u Senju i u Svetom Jurju, ali nije dokazano jesu li postojala dva samostana. ${ }^{37}$ Crkva u temeljima tvrđave Nehaj odgovara klasifikaciji malim starohrvatskim crkvama tipičnim za 10. i 11. stoljeće. Tlocrtno gledano crkva oblikom, apsidom, oltarom i tehnikom gradnje odgovara crkvi sv. Lucije u Jurandvoru, ali ne možemo biti sigurni kako je crkva unutar tvrđave bila benediktinska. ${ }^{38}$

\section{Benediktinski samostan i crkva sv. Križa}

$\mathrm{Na}$ početku Senjske Drage nalaze se ruševine koje bi mogle pripadati starom benediktinskom samostanu i crkvi sv. Križa. Pretpostavlja se kako nakon odlaska templara iz Senja 1269. godine, knezovi Frankopani dovode benediktince i smještaju ih u Senjsku Dragu. ${ }^{39}$ Jugoistočno uz Jozefinsku cestu, oko 1640. godine sagrađena je današnja crkva sv. Križa. Prema nekim spoznajama današnji ostatci crkve sv. Križa potječu iz nešto kasnijeg vremena (kada ove prostore naseljavaju Bunjevci). ${ }^{40} \mathrm{U}$ literaturi se navodi više teorija o točnoj lokaciji ovog prvog i najstarijeg samostana i crkve. ${ }^{41}$ Ante Glavičić navodi još jednu moguću lokaciju za samostan i crkvu, a to su Kaluđeri. Kaluđere spominje i Pavičić, koji piše kako to ime označava položaj južno od Vratnika u blizini potoka Kriški, koji je navodno i dobio ime po crkvi sv. Križa. ${ }^{42}$ Kako bi se saznalo nešto više o samostanu i crkvi, potrebno je izvršiti arheološka istraživanja.

\section{Crkva sv. Martina unutar Plave vile}

U Prvoj dragi nalazi se tzv. Plava vila unutar koje se nalazi srednjovjekovna romaničko-gotička crkvi posvećena sv. Martinu. Crkva je izgrađena 1330. godine kako to potvrđuju glagoljski natpisi, odnosno odljevi u njezinu pročelju. $\mathrm{Na}$ jednom spomeniku nalazi se slika sveca i biskupa Martina, dok se na drugome nalazi zanimljiv posvetni natpis - kazivanje predaka popa Ilije. ${ }^{43}$ Iz Plave vile potječe i zanimljiv pleterni ulomak koji se ne uklapa u prostor crkve sv. Martina. ${ }^{44}$

\footnotetext{
${ }^{37}$ A. GLAVIČIĆ, 2003, 33-34.

${ }^{38}$ A. GLAVIČIĆ, 1999, 99.

${ }^{39}$ A. GLAVIČIĆ, 1992, 99; 2003, 28.

${ }^{40}$ A. GLAVIČIĆ, 1992, 99; 2003, 29.

${ }^{41}$ Više o tome kod A. GLAVIČIĆ, 2003, 28-30.

${ }^{42}$ S. PAVIČIĆ, 1966, 338-339; A. GLAVIČIÍ, 2003, 30.

${ }^{43}$ A. GLAVIČIĆ, 2002, 40.

${ }^{44}$ A. GLAVIČIĆ, 2002, 40; 2003, 66-67.
} 
Ulomak je uzidan u tvrdu osnovu česme, a napravljen od vrste kamena koja nije iz senjske okolice te prikazuje antitetički postavljene, lijevo golubicu i desno grifona. Datira se u 11. stoljeće, u vrijeme kada je isklesana Senjska glagoljska ploča. Najviše sličnosti ima s ulomcima iz Osora. ${ }^{45}$

\section{Pavlinski samostan i crkva sv. Spasa}

U uvali Ljubotina kraj Senja nalaze se ostatci samostana i crkve sv. Spasa po kojima se uvala danas naziva Spasovac. Prvi put se samostan spominje 1364. godine, a napušten je i srušen zbog opasnosti turskog napredovanja tijekom 16. stoljeća. Pozicija je na samoj obali, na mjestu gdje se danas nalazi kamp Spasovac. Od njega danas nije puno ostalo, jedini vidljiv ostatak bivšeg samostana je podzid na strmim stijenama iznad mora. ${ }^{46}$ Prema izjavi vlasnika Krmpotića, pri uređenju gostionice nailazilo se na ljudske kosti. Stoga, možemo zaključiti kako se ispred crkve sv. Spasa nalazilo groblje u kojemu su pokapani redovnici samostana i stanovnici okolnih sela. ${ }^{47} \mathrm{Kada}$ se pri gradnji Nehaja ruše svi objekti izvan zidina grada, vjerojatno su srušena i oba pavlinska samostana, onaj u Vlaškoj dragi i ovaj u Ljubotini. ${ }^{48}$

\section{Crkva sv. Filipa i Jakova u Svetom Jurju}

Ispod današnje župne crkve sv. Jurja, uza samu morsku obalu, nasuprot otoka Lisca, nalazi se ruševina srednjovjekovne crkve sv. Filipa i Jakova te staro groblje koje ju okružuje. Radi se o jednobrodnoj crkvi s pravokutnom apsidom, asimetričnom bočnom kapelom i sakristijom između njih. Zidovi crkve sačuvani su gotovo u cijeloj svojoj prvotnoj visini. Ante Glavičić pretpostavlja kako crkva potječe iz 13. ili 14. stoljeća te pripada romaničko gotičkom graditeljstvu. ${ }^{49} \mathrm{Sa}$ istočne strane svetišta proteže se vanjski zid neke prvobitne zgrade koja danas čini sastavni dio ogradnog zida groblja. Fras u svojoj Topografiji navodi kako se kraj župne crkve i župnog dvora vide tragovi stare građevine koja bi mogla biti stari pavlinski samostan. ${ }^{50}$ No, kako bi se funkcija ovoga zida u potpunosti razjasnila potrebna su nova arheološka istraživanja.

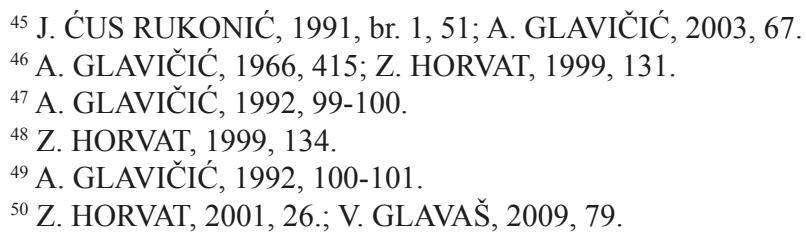


Sredstvima Ministarstva kulture provedena su zaštitna konzervatorskoarheološka istraživanja te konstruktivna i građevinska sanacija građevine. U prvoj fazi projekta konzervatorski radovi učinjeni su na samoj arhitekturi, statičkim i konstruktivnim saniranjem zidova te uređenjem interijera, zatim je istražen brod crkve. Blečić je svoja istraživanja usredotočila na brod crkve gdje je otkrila kompleks antičke arhitekture na kojoj je crkva bila sagrađena. ${ }^{51}$ U razdoblju od 16. studenog 2008. do 17. travnja 2009. godine istraživanja su nastavljena i ustanovljena je stratigrafska sekvenca od deset faza koje pripadaju antičkom, srednjovjekovnom i novovjekovnom dobu uključujući 11 novovjekovnih grobova. ${ }^{52}$ Iako se gradnja ove crkva uglavnom stavlja u 13 . stoljeće, ipak se još ne može točno odrediti vrijeme kada je crkva podignuta jer raspoloživi ostatci arhitekture nisu dovoljni za precizno datiranje.

\section{Jablanac}

Srednjovjekovno lučko i trgovačko naselje Albanić, današnji Jablanac, razvija se u malom zaljevu od 7. stoljeća, a od sredine 12. stoljeća postaje crkveno i župno središte većeg dijela Podgorja. ${ }^{53}$ Godine 1179. jablanački i bužanski župani izgradili su na brijegu iznad luke romaničku crkvu sv. Nikole. Godine 1251. hrvatski ban Stjepan Šubić dao je sagraditi iznad luke utvrđeni grad koji će živjeti od trgovine i pomorstva sve do kraja 15. stoljeća. Nakon oslobođenja Like i Krbave od Turaka, Jablanac su naselili Bunjevci. Izgradnjom nove crkve sv. Josipa pokraj mora polako se napušta crkva sv. Nikole koja postaje grobljanska i u toj funkciji ostaje do danas. ${ }^{54}$

\section{Karlobag}

Na području današnjeg Karlobaga smješta se rimskodobno naselje Vegij, koje propada tijekom seobe naroda u 6. i 7. stoljeću. Na Drvišici se nalazilo starohrvatsko naselje koje je napušteno na prijelazu iz 13. u 14. stoljeće. Tada se malo zapadnije razvija novo naselje $S c r i s s a-B a g$, koje s vremenom postaje važno trgovačko, prometno i vjersko središte čitave Podgorske župe. ${ }^{55} \mathrm{Na}$ zapadnim padinama Drvišice nalazi se crkva sv. Vida čija se gradnja, po dosadašnjim

\footnotetext{
${ }^{51}$ M. BLEČIĆ, 2006, 5-26.

${ }^{52} \mathrm{~V}$. GLAVAŠ, 2009, 67-82.

${ }^{53}$ A. GLAVIČIĆC, 1966, 397; 2003, 37.

${ }^{54}$ A. GLAVIČIĆ, 1966, 397; 2003, 37.

${ }^{55}$ A. GLAVIČIĆ, 1996, 47; 2003, 39.
} 
spoznajama, smješta u 13. stoljeće. ${ }^{56}$ Sačuvani su joj zidovi, pročelje i četvrtasta apsida. Istraživanja crkve sv. Vida provedena su 2014. i 2015. godine, ali rezultati još nisu objavljeni. ${ }^{57}$

\section{Crkva sv. Marije Magdalene u Tribnju (danas Sv. Marija Magdalena)}

Crkvica sv. Marije Magdalene, zvana još Trstenica, nalazi se u uvali Mandalina nakon Karlobaga. Radi se o maloj ruševnoj crkvici s natpisom iz 1181. godine. Crkva je obnovljena 1865. godine i smatra se sigurnim srednjovjekovnim sakralnim objektom što bi svakako buduća istraživanja trebala dokazati. ${ }^{58}$ Posljednjih godina je Arheološki muzej Zadar provodio zaštitna arheološka istraživanja same crkve te grobova u njoj i oko nje.

\section{Crkva sv. Petra u Starigrad-Paklenici}

Pred ulazom u kanjon Velike Paklenice, između Starigrada i Selina, smjestila se crkva sv. Petra. Radi se o srednjovjekovnoj i kasnosrednjovjekovnoj crkvi uz koju se pokapalo od ranog, preko srednjeg do novog vijeka. Crkvu i prostor oko nje prvi je istraživao lokani župnik don Ante Adžija, ali nažalost, nalazi njegovih istraživanja izgubljeni su tijekom II. svjetskog rata. Crkvu sv. Petra istraživali su mnogi, ali svakako treba istaknuti istraživanja jednog od autora ovog članka, Radomira Jurića, koji je sukcesivno vodio istraživanja unutar i oko crkve od 1999. godine do 2008. godine. ${ }^{59} \mathrm{U}$ ukupno devet istraživačkih kampanja utvrđeno je postojanje srednjovjekovne i kasnosrednjovjekovne crkve, kojima je dograđen zvonik, a kasnije i kontrafori na sjevernom i južnom zidu crkve. ${ }^{60}$ Od 2007. do 2012. godine na zvoniku i pročelju crkve izvršeni je konzervatorski zahvat pod stručnim nadzorom Uprave za zaštitu kulture i baštine, Konzervatorski odjel u Zadru s financijskom potporom Ministarstva kulture. Crkva je na taj način sačuvana od propadanja. ${ }^{61}$

${ }^{56}$ A. GLAVIČIĆ, 1996, 50; Pretpostavlja se kako je na tom mjestu i ranije moglo postojati neko starohrvatsko svetište te kako se radi o vjerskom nasljeđu starijeg poganskog starohrvatskog svetišta Svatnovida, odnosno Peruna.

${ }^{57}$ Istraživanja crkve sv. Vida na Drvišici proveo je Odjel za arheologiju Sveučilišta u Zadru.

${ }^{58}$ R. JURIĆ, 2010, 60-61.

${ }^{59}$ R. JURIĆ, 1995, 245-252; 2000, 24; 2001, 125-126; 2003, 649-658; 2005, 200-201; 2006, 316; 2007, 340-341; 2009, 504-505.

${ }^{60}$ R. JURIĆ, 2003, 653.

${ }^{61}$ R. JURIĆ, 2013, 649; 2009, 505. 


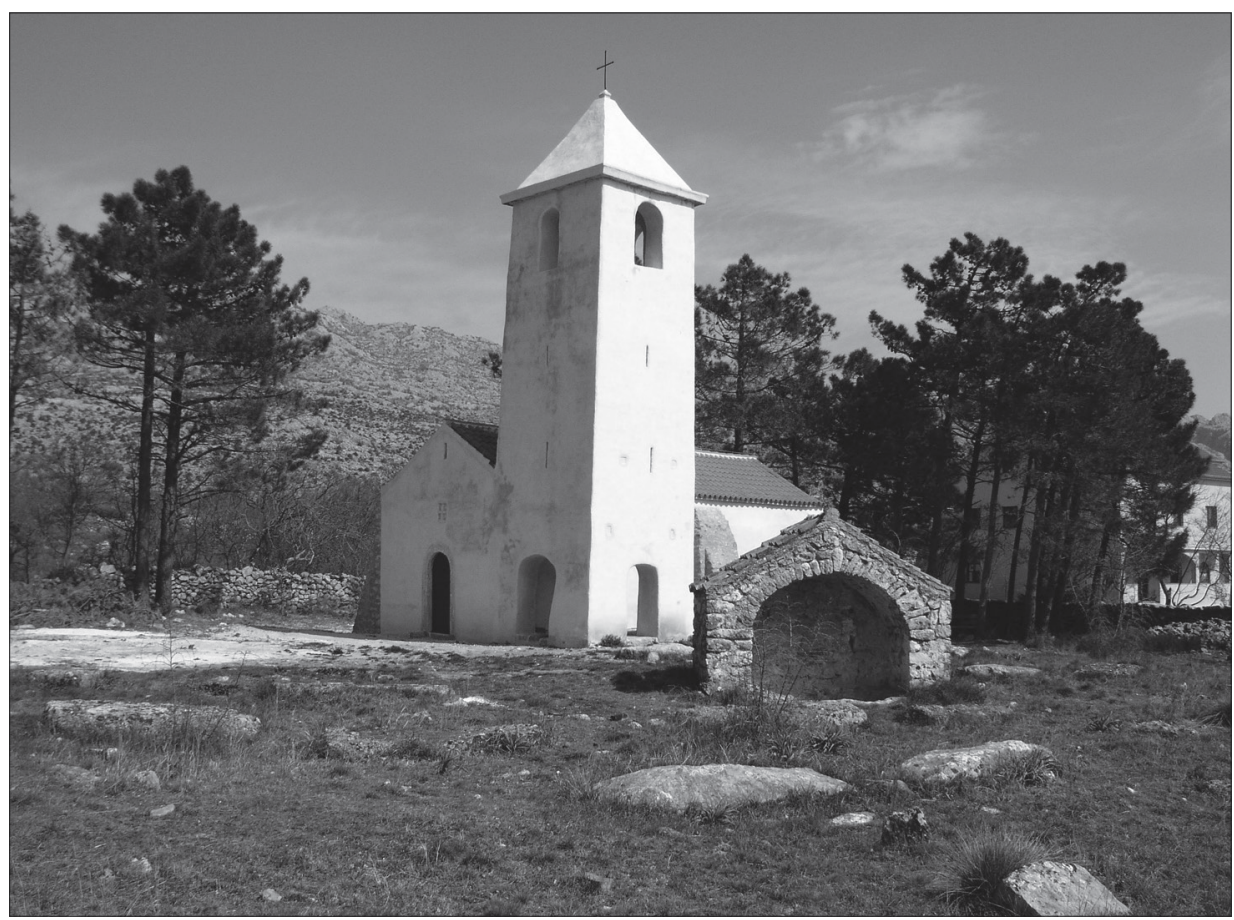

S1. 5. Crkva sv. Petra u Starigrad Paklenici, foto: Ivan Čondić

Treba spomenuti i romaničku crkvu sv. Jurja koja se smjestila u sredini rimskog Argirunta, u mjesnom groblju. Crkva ima neobičan, više gotički šiljasti luk i svod apside. ${ }^{62}$

\section{Crkva sv. Jurja u Rovanjskoj}

Još jedna crkva sv. Jurja nalazi se na groblju u Rovanjskoj. Crkva ima dva naknadno dograđena kraka koja stoje okomito okrenuti jedan prema drugome te izlaze iz jezgre svetišta koje je zapravo predromanička crkvica. Samo svetište ima tlocrt pravokutnika s polukružnom apsidom i presvođena je elipsastom kupolom na trompama. Naknadno dograđeni krakovi oštetili su sjeverozapadni i sjeveroistočno zid izvorne crkve. ${ }^{63}$ Postavlja se pitanje kada su nastala ta dva prigrađena kraka. Smatra se kako je stariji onaj sjeverozapadni, koji je mogao

\footnotetext{
${ }^{62}$ A. GLAVIČIIĆ, 2003, 40.

${ }^{63}$ I. PETRICIOLI, 1963, 177.
} 
nastati oko 12. stoljeća, dok je sjeveroistočni kraj nešto kasniji, ali nastao je negdje sredinom srednjeg vijeka jer se takav način presvođenja nije upotrebljavao nakon turskih ratova. ${ }^{64} \mathrm{~S}$ južne strane crkve prigrađena je grobnica u obliku akrosilija, odnosno kosturnice. Takva se nalazi i u blizini srednjovjekovne crkve sv. Petra u Starigrad-Paklenici. ${ }^{65}$ Crkva iz Rovanjske pripada tipu centralnih građevina s jednom apsidom kakve su još poznate na Dugom otoku, poput crkve sv. Pelegrina, a takve crkve datiraju se u 9. i 10. stoljeće. ${ }^{66}$

\section{Materijalna kultura}

Najviše srednjovjekovne materijalne kulturne pronađeno je u Senju. Već smo spomenuli kako je oko 1550. godine kapetan Ivan Lenković dao porušiti sve objekte koji su se nalazili izvan zidina i koji su bili prikladni za opsadu grada od Turaka, kako bi 1558. godine dovršio gradnju tvrđave Nehaj. Ne možemo biti sigurni kakva je sve spomenička baština ugrađena u Nehaj, ali možemo pretpostaviti kako se radi o spomenicima romanike, gotike i renesanse, od 11. pa sve do kraja 15. stoljeća. Ante Glavičić je ponudio dobar popis najvažnijih spomenika pronađenih u bedemima Nehaja. ${ }^{67}$

Kod južne strane katedrale sv. Marije pronađena su tri kasnoantička ranokršćanska ulomka rustične ornamentike, koja su vjerojatno pripadala oltarnoj pregradi, sarkofagu ili nekom drugom spomeniku povezanom s prvim kršćanskim objektom u Seniji iz prijelaza s 4. na 5. stoljeće. Na to je pitanje teško odgovoriti jer iz ovog razdoblja nemamo nikakvih pisanih vijesti. ${ }^{68} \mathrm{Na}$ nekoliko lokacija u Podgorju pronađeni su bizantski novci iz 6. stoljeća. Riječ je o brončanim novcima careva Justinijana I. i Justina II. iz Karlobaga, odnosno solidu Tiberija II. Konstantina s položaja Vinjerac kod Cesarice te brončanim primjercima istog cara iz Jurjeva. ${ }^{69}$

Katica Simoni navodi nekoliko dijelova konjaničke opreme ratnika, koji se danas čuvaju u Arheološkom muzeju u Zagrebu, a smatra se kako potječu iz starohrvatske Stinice. Radi se o 7 primjeraka brončanih okova i ulomku brončanog jezičca ukrašenog stiliziranom lozicom, što je karakterističan način ukrašavanja

\footnotetext{
${ }^{64}$ I. PETRICIOLI, 1963, 178.

${ }^{65}$ I. PETRICIOLI, 1963, 178-179.

${ }^{66}$ R. JURIĆ, 1995, 246.

${ }^{67}$ A. GLAVIČIĆ, 1999, 90.

${ }^{68}$ A. GLAVIČIĆ, 1982, 73-77; 2003, 65.

${ }^{69}$ Ž. TOMIČIĆ, 1990, 141.
} 
pojasnih garnitura $\mathrm{u}$ doba drugog avarskog kaganata. ${ }^{70}$ Nalazi se datiraju $\mathrm{u}$ drugu polovicu 8. stoljeća, u kasno avarsko razdoblje. Za sada su to jedini nalazi hrvatskoga srednjovjekovlja koji su ukrašeni stilom Blatnica na jadranskoj obali. ${ }^{71}$

Kada govorimo o materijalnoj kulturi srednjeg vijeka na ovim prostorima, ne možemo ne spomenuti Senjsku glagoljsku ploču. Znamenita ploča pronađena je pri uklanjanju stuba pred tvrđavom u nabacanom recentnom materijalu. Spomenik je bio ranije razbijen i ugrađen kao jedna od stuba ili prag vrata. Pronađeni kameni fragmenti imaju uklesane biljne ornamente, pleter i uglata glagoljska slova. ${ }^{72}$ Senjska glagoljska ploča datira se u kraj druge polovice 11. stoljeća te spada u zadnji stadij pleterne plastike, odnosno u ranoromaničku epohu kao i Bašćanska ploča. Radi se o gornjem dijelu lijevog pluteja oltarne pregrade koja potječe iz neke razgrađene crkve čiji je materijal ugrađen u Nehaj. Ante Glavičić smatra kako ulomci pripadaju crkvi sv. Jurja u temeljima Nehaja. ${ }^{73}$ Puno radova napisano je o Senjskoj glagoljskoj ploči, ali svakako treba izdvojiti rad Branka Fučića koji je izvršio idealnu rekonstrukciju ploče. ${ }^{74}$ Od pleterne plastike treba spomenuti i jedan ulomak s tzv. motivom osmice iz lapidarija Muzeja Like u Gospiću, za koji se smatra kako potječe iz Karlobaga. Prema analogijama ulomak se datira u 11. stoljeće i pretpostavlja se kako potječe iz crkve sv. Ivana. ${ }^{75}$

Već smo spomenuli don Adžiju, koji je u crkvi sv. Petra pronašao nekoliko ulomaka starohrvatske pleterne plastike, koje datira od 8. do 10. stoljeće, no taj materijal je izgubljen. ${ }^{76} \mathrm{Na}$ starim fotografijama crkve može se uočiti oko 50 većih i manjih grobnih ploča, odnosno stećaka. Neki su obilježeni križem ili nekim drugim simbolom. Danas ih je većina nestala, a one koje su ostale poprilično su oštećene. ${ }^{77} \mathrm{U}$ devet istraživačkih kampanja pod vodstvom Radomira Jurića, u crkvi sv. Petra i oko nje pronađeno je ukupno 215 grobova s nalazima od ranog srednjeg do novog vijeka. Pokojnici su polagani u grobove $\mathrm{s}$ arhitekturom ili izravno u zemlju, ali prevladavaju ovi prvi. ${ }^{78}$ Pronađeno je preko 300 raznih predmeta među kojima je najviše nakita iz kasnog srednjeg vijeka. Najviše su zastupljene naušnice i prstenje, u više tipova i inačica. ${ }^{79}$

\footnotetext{
${ }^{70}$ K. SIMONI, 1986, 217-218.

${ }^{71}$ K. SIMONI, 1986, 222.

${ }^{72}$ A. GLAVIČIĆ, 1965, 315-322.

${ }^{73}$ A. GLAVIČIĆ, 1999, 89-114.

${ }^{74}$ B. FUČIĆ, 1973, 121-132.

${ }^{75}$ A. GLAVIČIĆ, 2003, 61.

${ }^{76}$ R. JURIĆ, 1995, 246.

${ }^{77}$ R. JURIĆ, 2001, 125-126.

${ }^{78}$ R. JURIĆ, 2013, 649.
} 


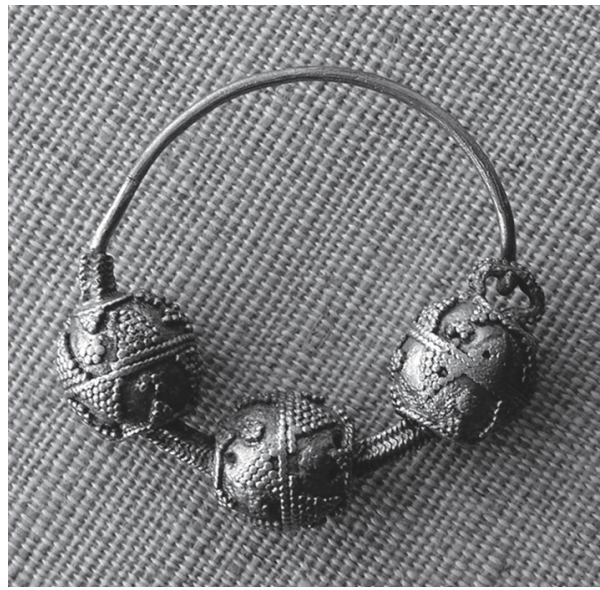

S1. 6. Starigrad Paklenica - Sv. Petar. Trojagodna naušnica, foto: Ivan Čondić

Treba izdvojiti nekoliko primjeraka trojagodnih naušnica različitih tipova koji se datiraju na sam kraj 13., kroz 14., pa sve do početka 15 . stoljeća. U grobovima i izvan njih pronađeno je nekoliko kasnosrednjovjekovnih novčića. ${ }^{80}$ Svakako treba spomenuti i nalaze dijelova dijademe, aplika, pređica, brončana puceta, ulomci brončanih igala, brončani medaljon, omega sponice, željezne strelice te nalazi keramike i stakla. ${ }^{81} \mathrm{O}$ nalazima će se iscrpnije govoriti prilikom monografske obrade cijelog istraženog groblja.

\section{Zaključna razmatranja}

Iseljenjem starosjedilaca iz velebitskog Podgorja početkom 16. stoljeća prekinuta je narodna tradicija senjskog i podgorskog kraja. Propala su mnoga naselja i zaboravilo se mnogo toga što bi nam danas pomoglo u istraživanju ovog prostora. Bio je ovo sažeti prikaz najznačajnijih, srednjovjekovnih, kulturnopovijesnih lokaliteta s pripadajućim arheološkim materijalom na prostoru od Senja do Rovanjske. Rezultati su svakako respektabilni s obzirom na količinu istraživanja. Međutim, istraživanja valja nastaviti, pa rezultati sigurno neće izostati. Svakako postoji još lokaliteta koji možda nisu ubicirani ili su jako loše očuvani, stoga ovaj dio Hrvatske zaslužuje mnogo veću pozornost.

\footnotetext{
${ }^{79}$ R. JURIĆ, 2013, 649.

${ }^{80}$ R. JURIĆ, 2013, 650.

${ }^{81}$ R. JURIĆ, 2005, 200-201; 2006, 316; 2007, 340-341; 2009, 504-505.
} 


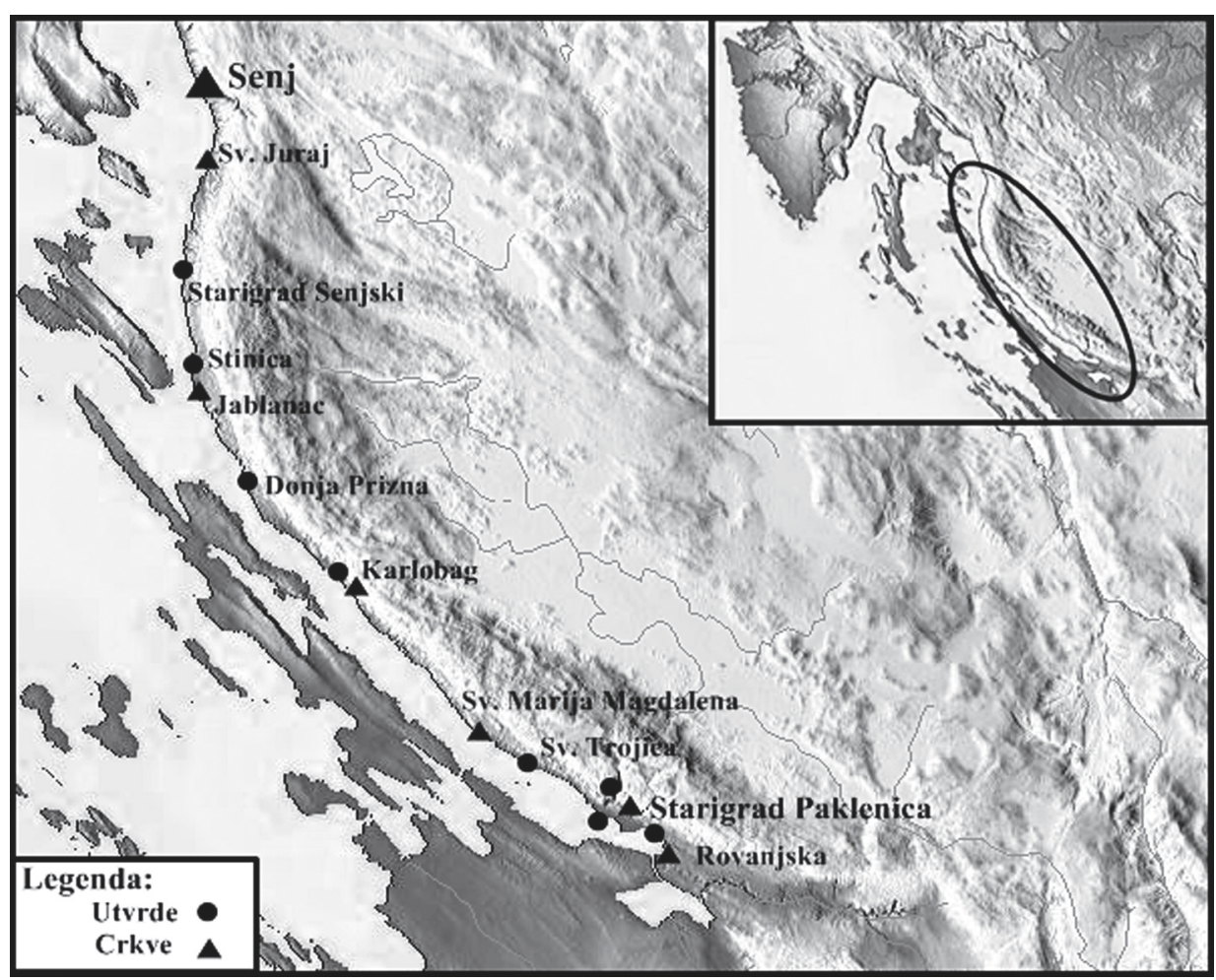

S1. 7. Karta srednjovjekovnih lokaliteta u velebitskom Podgorju, autorica: Iva Škoro

\section{Literatura}

Martina BLEČIĆ, Zaštitna arheološka istraživanja crkve sv. Filipa i Jakova u Svetom Jurju, Senjski zbornik, 33, Senj, 2006, 5-26.

Jasminka ĆUS RUKONIĆ, Predromanička, protoromanička i ranoromanička skulptura na otocima Cresu i Lošinju, 1991.

Slobodan ČAČE, Civitates Dalmatiae u "Kozmografiji" Anonima Ravenjanina, Zadar, 1995. Ivica DEGMEDŽIĆ, Arheološka istraživanja u Senju, Vjesnik za arheologiju i historiju dalmatinsku, LIII (1950-1951), Split, 1952, 251-262.

Branko FUČIĆ, Senjska ploča, Senjski zbornik, 5, Senj, 1973, 121-132.

Vedrana GLAVAŠ, Crkva sv. Filipa i Jakova u Svetom Jurju - rezultati novih istraživanja, Senjski zbornik, 36, Senj, 2009, 67-82.

Ante GLAVIČIĆ, Izvještaj o značajnim arheološkim nalazima u tvrđavi Nehaj u Senju 1964. godine, Senjski zbornik, 1, Senj, 1965, 315-322.

Ante GLAVIČIĆ, Arheološki nalazi iz Senja i okolice I., Senjski zbornik, 2, Senj,1966, 384-426. 
Ante GLAVIČIĆ, Arheološki nalazi iz Senja i okolice (V.), Senjski zbornik, 9, Senj, 1982, 63-90.

Ante GLAVIČIĆ, Arheološki nalazi iz Senja i okolice (VI.), Senjski zbornik, 10-11, Senj, 1984, 7-28.

Ante GLAVIČIĆ, Stara i nova groblja, grobovi na području grada Senja i šire Senjske okolice (I), Senjski zbornik, 19, Senj, 1992, 81-108.

Ante GLAVIČIĆ, Ostaci crkve Sv. Vida u Senju i Karlobagu: Prilog istraživanju starohrvatskih sakralnih objekata Velebita - II. dio, Senjski zbornik, 23, Senj, 1996, 41-58.

Ante GLAVIČIĆ, Dopunjeno izvješće o otkriću Senjske glagoljske ploče u povodu 900. obljetnice njezina postojanja, Senjski zbornik, 26, Senj, 1999, 89-114.

Ante GLAVIČIĆ, Obnova katedrale Blažene Djevice Marije u Senju 2001. Nalaz srednjovjekovne crkve na mjestu sakristije, Senjski zbornik, 28, Senj, 2001, 33-50.

Ante GLAVIČIĆ, Novi nalazi starohrvatskog pletera. Prilozi istraživanju sakralne arhitekture u Senju, Senjski zbornik, 29, Senj, 2002, 29-46.

Ante GLAVIČIĆ, Starokršćanska i ranosrednjovjekovna baština Like, Podgorja i grada Senja, Senjski zbornik, 30, Senj, 2003, 21-82.

Zorislav HORVAT, Srednjovjekovna pavlinska arhitektura na području senjske i modruško-krbavske biskupije, Senjski zbornik, 26, Senj, 1999, 123-178.

Zorislav HORVAT, Ruševna crkva na groblju sv. Filipa i Jakova u Sv. Jurju kraj Senja, Senjski zbornik, 28, Senj, 2001, 21-32.

Radomir JURIĆ, Srednjovjekovni spomenici u Velebitskom Podgorju, Paklenički zbornik, 1, Starigrad-Paklenica, 1995, 245-253.

Radomir JURIĆ, Crkva Sv. Petra u Starigradu-Paklenici (sažetak), Obavijesti Hrvatskoga arheološkoga društva, 2, Zagreb, 2000, 24.

Radomir JURIĆ, Starigrad-Sv. Petar, 2001, Obavijesti Hrvatskoga arheološkoga društva, br.3, god. 33, Zagreb, 2001, 125-126.

Radomir JURIĆ, Starigrad (Paklenica), Paklarić, Obavijesti Hrvatskog arheološkog društva, br.1, god. 34, Zagreb, 2002, 90-93.

Radomir JURIĆ, Crkva Sv. Petra u Starigradu-Paklenici, Senjski zbornik, 30, Senj, 2003, 649-658.

Radomir JURIĆ, Starigrad Paklenica-Sv. Petar, Hrvatski arheološki godišnjak, 1/2004, Zagreb, 2005, 200-201

Radomir JURIĆ, Starigrad Paklenica-Sv. Petar, Hrvatski arheološki godišnjak, 2/2005, Zagreb, 2006, 316.

Radomir JURIĆ, Starigrad Paklenica-Sv. Petar, Hrvatski arheološki godišnjak, 3/2006, Zagreb, 2007, 340-341.

Radomir JURIĆ, Starigrad Paklenica-Sv. Petar, Hrvatski arheološki godišnjak, 5/2008, Zagreb, 2009, 504-505.

Radomir JURIĆ, Arheološka topografija Tribnja; Mirila: kulturni fenomen, urednik: Andrej Pleterski et al., Ljubljana : Inštitut za arheologijo ZRC SAZU, Založba ZRC, 2010, 55-61. 
Radomir JURIĆ, Arheološka istraživanja crkve sv. Petra i njezina okoliša u Starigradu Paklenici, Senjski zbornik, 40, Senj, 2013, 647-656.

Stjepan PAVIČIĆ, Raseljenje starosjedilaca i doseljenje Bunjevaca u Senjski kraj, Senjski zbornik 2, Senj, 1966, 309-382.

Ivo PETRICIOLI, Crkva sv. Jurja u Rovanjskoj, Starohrvatska prosvjeta, sv. 8-9, Institut za Nacionalnu arheologiju Jugoslavenske Akademije znanosti i umjetnosti u Splitu, Zagreb, 1963, 177-180.

Ksenija SIMONI, Neobjavljeni okovi i jezičci nakitnoga stila blatnica iz Arheološkog muzeja u Zagrebu, VAMZ 3, XIX, 1986, 217-228.

Ranko STARAC, Rezultati prve faze arheoloških sondiranja na trgu Cimiter u Senju, Senjski zbornik, 26, Senj, 1999, 71-88.

Željko TOMIČIĆ, Materijalni tragovi ranobizantskog vojnog graditeljstva u velebitskom Podgorju, VAMZ XXIII, Zagreb, 1990, 139-162.

Melita VILIČIĆ, Grafička rekonstrukcija katedrale sv. Marije u Senju, Senjski zbornik, 3, Senj, 1968, 54-87.

\section{MEDIAEVAL ARCHAEOLOGICAL SITES IN PODGORJE}

\section{Summary}

In the area from Senj to Maslenica many mediaeval sites have been documented. They are fortresses, sacral buildings and cemeteries from $5^{\text {th }}$ to $16^{\text {th }}$ centuries. Archaeological localities and the related finds from the areas of Senj, Sveti Juraj, Senj Starigrad, Stinica, Prizna, Jablanac, Karlobag, Starigrad-Paklenica and Rovanjska, which belong to early Christianity and the Croatian Middle Ages will be elaborated upon. The contribution is based on the results of previous archaeological research and surveys, which are already known and their own research.

Keywords: Podgorje, Senj, early Christianity, Middle Ages, fortresses, churches, monasteries 